\title{
Método, modelo e memória: \\ Perspectiva Pictorum et Architectorum, de Andrea Pozzo
}

\author{
Mateus Alves Silva*
}

\begin{abstract}
Resumo No final do século XVII o jesuíta Andrea Pozzo (1642 - 1709) publicou, em Roma, o tratado Perspectiva Pictorum et Architectorum (1693 e 1700). Essa obra objetivava apresentar a pintores e arquitetos um modo prático e rápido de se realizar a perspectiva. Por esse caráter, a obra conheceu rápida difusão, sendo reeditada, impressa e traduzida em diversas línguas. Neste artigo discutem-se questões relativas ao tratado, em três vias: como um método didático de se realizar desenhos em perspectiva, baseado na experiência do autor; como modelo para a arquitetura, em função da representação de formas clássicas e de invenções e novas soluções; e, por fim, como memória dos feitos do autor e da Companhia de Jesus, da qual fazia parte.
\end{abstract}

Palavras-chave: Andrea Pozzo, tratados de arte, perspectiva.

\section{Método, modelo y memoria: Perspectiva Pictorum et Architectorum, de Andrea Pozzo}

Resumen A finales del siglo XVII, el jesuita Andrea Pozzo (1642 - 1709) publicó en Roma el tratado Perspectiva Pictorum et Architectorum (1693 y 1700). Este trabajo tuvo como objetivo presentar a pintores y arquitectos una forma práctica y rápida de realizar la perspectiva. Debido a esto, el tratado se difundió rápidamente, siendo reimpreso y traducido a varios idiomas. Este artículo discute temas relacionados con el tratado, de tres formas: como método didáctico para hacer dibujos en perspectiva, basado en la experiencia del autor; como modelo para la arquitectura, debido a la representación de formas clásicas, invenciones y nuevas soluciones; y, finalmente, como memoria de las obras del autor y de la Compañía de Jesús, de la que formó parte.

Palabras clave: Andrea Pozzo, tratados de arte, perspectiva.

\section{Method, model, and memory: Perspectiva Pictorum et Architectorum, by Andrea Pozzo}

Abstract At the end of the XVIlth century, the Jesuit Andrea Pozzo (1642 - 1709) published in Rome the treatise Perspectiva Pictorum et Architectorum (1693 e 1700). This work aimed to present to painters and architects an easy and quick method to make perspectives. The treatise was largely known and was re-edited, reprinted, and translated in several languages. In this paper we discuss questions about the treatise in three ways: as a didactical method to make perspective designs, based on the author's experience; as an architectural model with its representations of classical forms, inventions, and new solutions; and, at last, as a memory of the author and of the Society of Jesus, which he has been part of.

Keywords: Andrea Pozzo, art treatises, perspective. 
* Mateus Alves Silva é Historiador, Doutor em História pela Universidade Estadual de Campinas, ORCID <https://orcid.org/00000003-0250-2912>.
Em 1693 o jesuíta Andrea Pozzo (Trento, 1642 - Viena, 1709), publicou, em Roma, o primeiro volume de um tratado de perspectiva intitulado Perspectiva Pictorum et Architectorum, ou A Perspectiva dos Pintores e dos Arquitetos, cujo objetivo era apresentar um método eficaz de construção de desenhos de perspectiva arquitetônica, fundamentais para os aprendizes de ambas as áreas. Mais tarde, em 1700, o segundo volume foi publicado contendo um novo método, considerado ainda mais fácil e de rápida execução, baseado na prática de seu autor. Pozzo, na altura das publicações, encontrava-se em Roma, realizando as maiores encomendas para a Companhia de Jesus, das quais três podem ser consideradas as principais: a decoração pictórica do corredor da Casa Professa (c. 1682-1685), que dava acesso aos aposentos em que viveu Santo Inácio de Loiola, fundador da Ordem Jesuíta (figura 1); todo o programa decorativo da Igreja de Santo Inácio do Colégio Romano jesuíta (1685-1694), que incluía, dentre várias contribuições as famosas pinturas da falsa cúpula (figura 4) e do teto da nave (figura 5), ambos em perspectiva; e o projeto arquitetônico para o altar que guarda os restos mortais de Santo Inácio (1695-99) (figura 8), na Igreja de Jesus ( I/ Gesù ), a casa-mãe dos jesuítas. Tais obras atestam a sua autoridade e notoriedade na condução de obras da Companhia, assim como permitiram a transferência posterior para Viena, coração do Sacro Império, onde permaneceria até a sua morte em 1709.

Neste trabalho pretendemos analisar alguns aspectos relativos ao tratado de Pozzo, por ser uma referência na literatura artística de fins do século XVII que se estendeu em diversas reimpressões, novas edições e traduções para várias línguas ao longo do século XVIII. O objetivo é compreender alguns pontos que poderiam ser responsáveis por essa expressiva difusão do tratado, e que se resumem em três vias complementares: a organização do tratado como um método para a projeção e desenho em perspectiva, baseado na prática direta do artista; a divulgação desse método como um modelo para a representação da arquitetura em perspectiva, partindo dos elementos mais singulares das ordens arquitetônicas clássicas até o seu desenvolvimento por invenções e adaptações, motivadas pelo autor; e, sobretudo, a estruturação do tratado como um mecanismo de memória, tanto dos feitos do artista em pintura e arquitetura quanto das peças da própria Companhia de Jesus, registradas em pormenores na obra.

Para chegarmos a essas vias partimos da análise direta dos volumes do tratado e suas edições e traduções, associando-os a outros exemplares fundamentais da história da perspectiva, além do cotejamento com a produção artística de Pozzo e com que estava sendo produzido para a Companhia de Jesus naquele final de século.

\section{Os volumes de Perspectiva Pictorum et Architectorum}

O primeiro volume de Perspectiva Pictorum et Architectorum surgiu em 1693, portanto, no período em que Pozzo, aos 51 anos de idade, trabalhava incessantemente nas obras da Igreja de Santo Inácio em Roma. 
Figura 1: Corredor da Casa Professa, Roma. Fonte: do autor.

\footnotetext{
1 Um dos biógrafos clássicos de Andrea Pozzo de princípios do século XVIII, Francesco Saverio Baldinucci (filho do conhecido Filippo Baldinucci), explicitou essa ação de Pozzo na sua biografia, determinando, inclusive, os possíveis valores das obras realizadas ( ascendente sopra duemila scudi) — tanto na Igreja como fora dela — que poderiam ter dado condições financeiras para que o intuito do artista se realizasse (BALDINUCCI, 1975, p. 327 [134r-134v]) (SALVIUCCI INSOLERA, 1996, p. 207). A biografia feita por Baldinucci, assim como os demais documentos que narram a vida de Pozzo foram analisados em seus pormenores por Evonne Levy (LEVY, 2011).
}

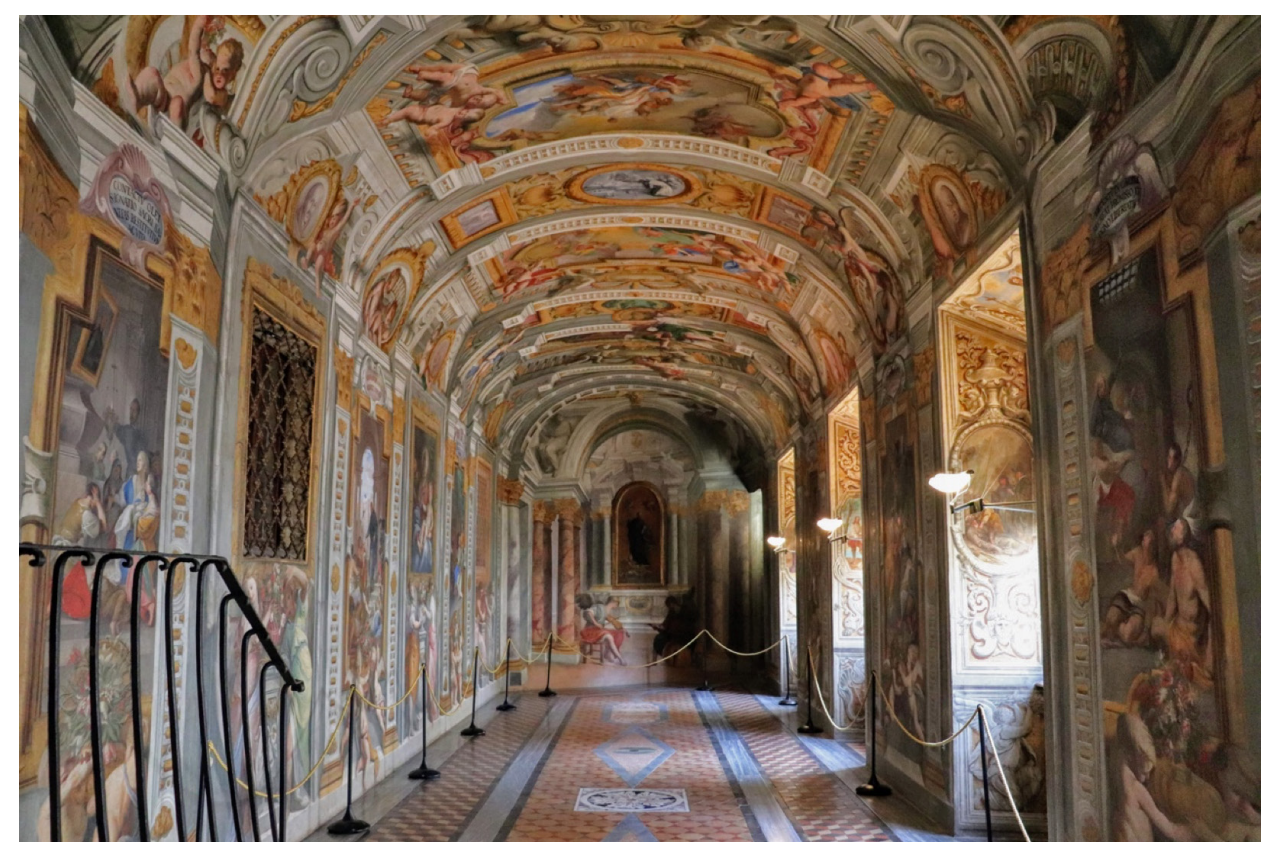

Nessa altura, parte das pinturas já estava concluída, principalmente a falsa cúpula no transepto, mas ainda estava em processo a grande pintura da abóbada da nave. Mesmo com a maior de suas obras inconclusa, Pozzo se valeria dos ganhos daquela empreitada para dar luz ao livro que estava preparando, desobrigando também a própria Companhia dos custos relacionados à publicação'.

No que diz respeito aos motivos da publicação, é o próprio autor quem nos dá indicação. Por se entender já como perito na arte da perspectiva e por compreender a função dupla dessa arte para pintores e arquitetos, Pozzo pretende estabelecer os princípios da arte, devido à falta de métodos que realmente comunicassem de forma útil a prática da perspectiva, endereçando-a aos praticantes de ambas as artes:

(...) entre tantos corajosos que até aqui se meteram em tal empresa, não são poucos os que rapidamente perderam os ânimos por falta de mestres e livros que ensinariam a dar à Perspectiva os seus escorços, dos princípios da arte até a sua total perfeição. Encontrando-me na posição de ter conseguido alguma facilidade nessa profissão, com o exercício contínuo por muitos anos, considero poder satisfazer aos Estudiosos, e cooperar para o seu proveito, dando à luz os modos mais rápidos com os quais podem ser desenhadas em perspectiva todas as Ordens da Arquitetura, por via da Regra Comum, abolindo dessa todas as confusões das linhas ocultas. (I, Ao Leitor estudioso da Perspectiva)

Pozzo comunica-se diretamente com o público ao escrever a sua obra, quase como se pretendesse se tornar o possível mestre a que se refere na exortação ao leitor. Essa escolha discursiva abre espaço não apenas para a criação da relação mestre-aprendiz, 
2 Esse arranjo do livro ecoa alguns formatos da tratadística clássica de arquitetura, como na orientação do texto em função das figuras presente na Regola delle cinque ordini d'Architettura (1562) de Jacopo Barozzi da Vignola (1507-1573) ou mesmo nas diversas edições do Tratado de Arquitetura de Sebastiano Serlio (1475-1553/5) (em especial na publicação dos volumes I e II, Geometria e Perspectiva - 1545), em que o texto é disposto em francês e italiano.

Figura 2: Disposição do texto e imagem. Fonte: Perspectiva Pictorum et Architectorum, vol. I, fig. 1. como justifica também toda a forma de disposição do tratado: toda a publicação é baseada na sucessão de imagens e, junto a elas, a sua explicação em forma de pequenos textos, apresentados em duas línguas: latim e italiano. Os textos são apresentados à esquerda, seguindo a orientação (vertical ou horizontal) das imagens à direita (figura 2). Texto e imagem são interdependentes, sendo um a facilitação da compreensão do outro: o que falta ao texto está na imagem e vice-versa (MARIANI, 2010, p. 89)².

O intuito de Pozzo na publicação não era a simples composição de um manual e a publicação consistia em dois tomos ricamente ilustrados (BÖSEL e SALVIUCCI INSOLERA, 2010, p. 164), o que se justifica pelo seu formato, in folio (c. $43 \times 24 \mathrm{~cm}$ ). O tamanho influenciava sobretudo a disposição da imagem, garantindo assim o detalhamento necessário tanto para o entendimento do método quanto para a apreciação dos diversos exemplos citados, a maioria deles de obra do próprio autor. Como dito, já se tinha por intenção a publicação em dois volumes, o que se justificaria pela apresentação diferente da "regra comum", na qual Pozzo exporia a forma como ele próprio compunha seus

\section{F I G UR A P R I M A.} Explicatio linearum plani \& horizontis,
oculi \& diftantix.

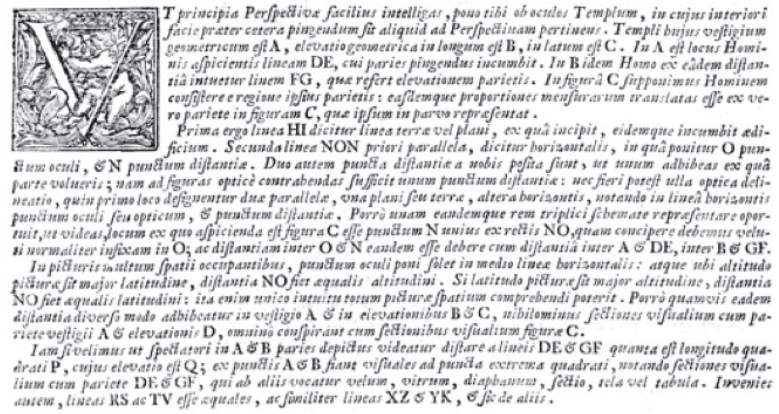

\section{F I G U R A P R I M A.}

spiegatione delle linee del piano e dell' orizzonte, e d' punti dell occbóo e della diftanza.

Ccioche meglio intendiatec i principii dellla Profpetriua, vi pongo innanziagli occhi una
Chiefí, in tefta della qualc, fra le altre cofedebba dipingerli qualche Profipettiva. Quefta

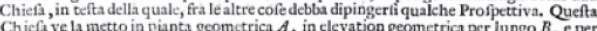
largo $C$. In $A 2$ ill luogodonde un Huomo rimira $\mathrm{L}$ l linea $D E$, che è la pianta della muraglia da dipingerfi. In $B$ liftect' Huomo dalla medefima diftanza mira la linea $F G$, che

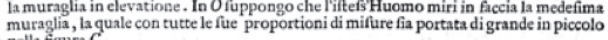
nella igura $C$.
Dunque la prima linea $H I$ chiamafi linea della terra o del piano, dove pofa o donde co-

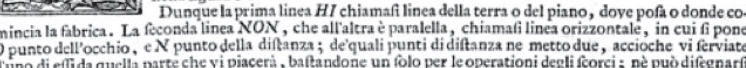

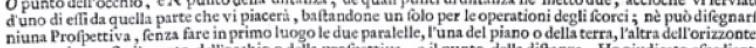

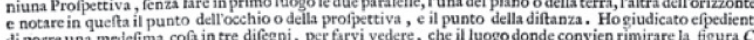

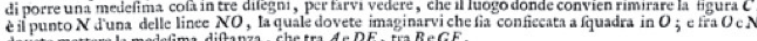

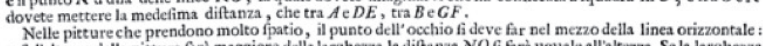

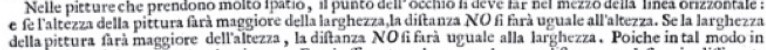
un'occhiata fi foorgera tutta la pirtura. E qui offervate, che ancorche una diftanza medefima in differente

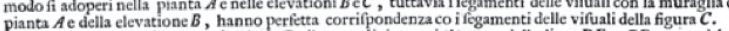
Se volete che allo fipettatore in $A$ e in $B$, il murodipinto paja lontano dalle linee $D E$, e $G F$ quanto $\dot{e}$ lungo il quadro $P$, Televatione del qualee $Q Q$, da i punti $A$ es tarete

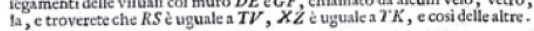
Figura 2

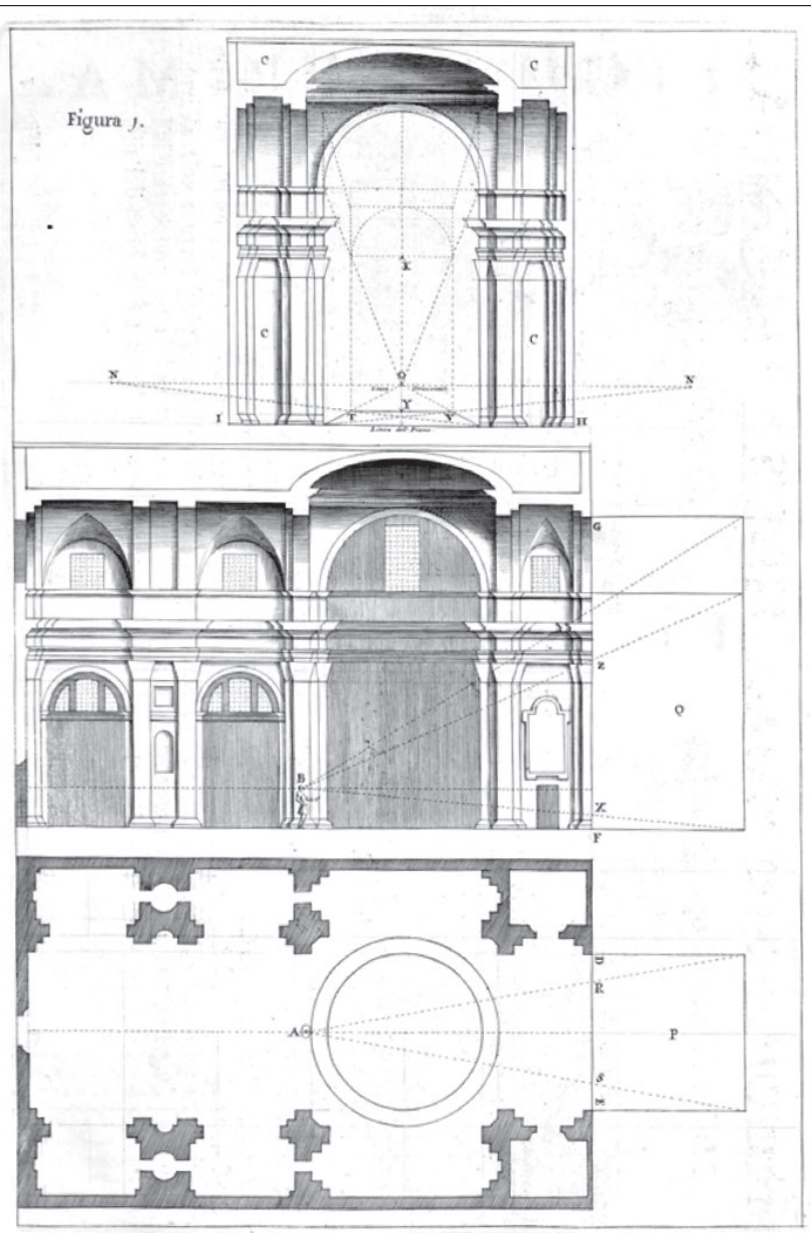


3 Pozzo assim descrevia: "Em seguida, se a Bondade Divina me der tempo e força para compor outro livro, mostrarei o modo de fazer toda a Perspectiva com a Regra que atualmente adoto, que é mais fácil e universal do que a ordinária e comum (ainda que essa seja fundamento daquela)." (I, Ao Leitor estudioso da Perspectiva). As citações ao tratado seguirão sempre com o volume a que se refere seguido do número da figura correspondente ou o seu título (ex.: I, 31).

4 Importa citar que das 223 imagens que compõem os dois volumes do tratado (102 no $1^{\circ}$ volume e 121 no $2^{\circ}$ ) 190 matrizes em cobre foram adquiridas pelo Ministero per i Beni e le Attività Culturali e destinadas à coleção da Calcoteca do Istituto Nazionale per la Grafica em 2008, correspondendo a um grande e importante acervo sobre a técnica utilizada na impressão desses volumes (MARIANI, 2010, p. 89).

5 Há um único exemplar de desenho original no Arquivo do Colégio Húngaro-Alemão, feito já de forma espelhada como base de preparação para a matriz de impressão, correspondendo à figura I, 36 do tratado. (BÖSEL e SALVIUCCI INSOLERA, 2010, p. 168-169). Quanto aos alunos que colaboraram na elaboração das matrizes, o nome principal é o de Vincenzo Mariotti (1650-1734), que realizou a maior parte das gravuras presentes no primeiro volume do tratado. (MARIANI, 2010, p. 91-92)

6 "Quero sugerir aqui um conseIho importantíssimo, qual seja, de que vos contenteis em bem entender a segunda figura antes de passar à terceira; e o mesmo digo de todas as outras, pois, sendo dispostas com tal ordem, a qualquer uma que vá adiante é necessário ter compreendido aquela que vem anteriormente". (I, Avisos aos principiantes) desenhos de perspectiva ${ }^{3}$. De outro ponto, pode-se considerar também que esse segundo volume se inclinaria mais à apresentação das obras realizadas pelo autor segundo essa regra, compondo mais da metade do volume.

Pozzo foi muito cauteloso no processo de elaboração das imagens que servem ao tratado, tanto que comenta, em alguns momentos, sobre a dificuldade em traduzir no desenho tudo o que pretendia apresentar, em virtude do tamanho do fólio ou, ainda, em relação à falta de habilidade do gravurista. Por essa razão acompanhou de perto a produção das chapas de cobre que serviriam à impressão ${ }^{4}$, colocando para essa realização inclusive alguns de seus alunos que se dedicavam à arte da gravura ${ }^{5}$.

Com as gravuras realizadas, a obra foi impressa em 1693 por Giovanni Giacomo Komarek (1648-1706), que mantinha uma oficina tipográfica próximo à antiga Igreja do Santo Anjo da Guarda no Tritão (Santo Angelo Custode al Tritone - demolida em 1928-29) (TINTO, 1973, p. 197). A publicação parece ter tido relativo sucesso imediato, o que daria meios para a publicação de um segundo volume, sete anos mais tarde.

O primeiro volume de Perspectiva Pictorum et Architectorum contempla uma série de temas que poderiam ser, a princípio, díspares entre si, apresentando pouca conexão. $O$ autor, contudo, cria por meio do texto uma forma de alinhavar todas as temáticas, partindo do pressuposto que o grau de dificuldade dos exemplos de perspectiva apresentados cresceria. Exatamente por essa razão é que o autor estimula os leitores a compreender bem as figuras antes de passar às próximas ${ }^{6}$, de modo a estabelecer um padrão gradual do aprendizado sobre a perspectiva e sua aplicação no campo da pintura e da arquitetura.

O tratado se inicia com uma dedicatória a Leopoldo I, imperador do Sacro Império Romano Germânico. O endereçamento ao imperador austríaco e não a um determinado papa ou cardeal, como se vê em demais exemplos da tratadística, pode ser lido em duas frentes: de um lado, a necessidade de se distanciar das disputas dentro da hierarquia católica que poderiam Ihe causar prejuízos na distribuição da obra (como diversas vezes ocorreu durante a trajetória de Pozzo); de outro, há a possibilidade de um direcionamento prático direto com a chance de sua transferência para a corte de Viena, como de fato ocorreu a partir de 1702. De qualquer modo, é muito significativo compreender essa dedicatória na chave dos interesses para a publicação do tratado Perspectiva Pictorum et Architectorum.

O ponto chave da dedicatória de Pozzo a Leopoldo l é a memória. Por essa razão ergue, na gravura que acompanha a abertura do tratado (figura 3), um monumento dedicado ao Imperador cujo triunfo dos feitos passados é celebrado por meio das artes. Para se registrar a memória do reinado, o desenho se torna ainda mais importante que a própria construção arquitetônica, pois é capaz de sobreviver a ela, o que exige que os monumentos sejam correta e precisamente representados. Vem daí a necessidade de um estudo aprofundado da perspectiva: "pois frequentemente ocorre que a durabilidade dos Papéis sobreviva à longevidade dos monumentos, ainda que feitos em mármore" (I, à Sacra Majestade do Imperador). Com essa afirmação Pozzo parece apresentar uma possibilidade legítima de que os papéis, ou seja, os textos - e por extensão, os tratados - sejam compreendidos a partir da sua durabilidade no tempo, aquilo que a arquitetura, mesmo sendo marmórea, não permite a qualquer de seus edifícios. Uma vez que os edifícios construídos têm a possibilidade de serem destruídos 
7 Para um maior detalhamento da organização do tratado, ver Silva (2012 e 2020).

Figura 3: À Sacra Majestade do Imperador Leopoldo Austríaco. Fonte: Perspectiva Pictorum et Architectorum, vol. I. ou tornarem-se ruínas, os papéis gravados poderiam ser a chave da permanência e da fixação ao longo das eras, permitindo a memória daquilo que fora produzido. Tal contribuição eleva o texto à durabilidade das obras de arquitetura, como uma possibilidade de monumentalizar o próprio texto.

O tratado se organiza em torno de alguns temas principais ${ }^{7}$. Primeiramente apresenta alguns pressupostos para a leitura do texto (como visto anteriormente) e suas definições da perspectiva. A partir de então, passa à disposição em perspectiva das figuras geométricas planas e sólidas (I, 1-7) e de cada um dos elementos das ordens arquitetônicas (l, 8-37), para daí fazer as primeiras construções arquitetônicas completas (I, 38-51), com uma breve inserção sobre a coluna torsa (52-53). Em seguida, o autor condensa todo o conhecimento apresentado em pormenores e passa a apresentar projetos construídos e não construídos, principalmente dos aparatos efêmeros para as festividades religiosas (I, 54-60). Os exemplos de estruturas temporárias, por terem sido pintados, exigem uma explicação específica sobre a disposição do desenho perspéctico em múltiplas telas dispostas em profundidade (I, 61-62). Segue então com mais três projetos de arquitetura efêmera realizados na Igreja de Santo Inácio ou na Igreja de Jesus (I, 63-71) que, por serem considerados "teatros sacros", se contrapõem aos "teatros cênicos", tema que trata como possibilidade de uso da perspectiva $(\mathrm{I}, 72-77)$.

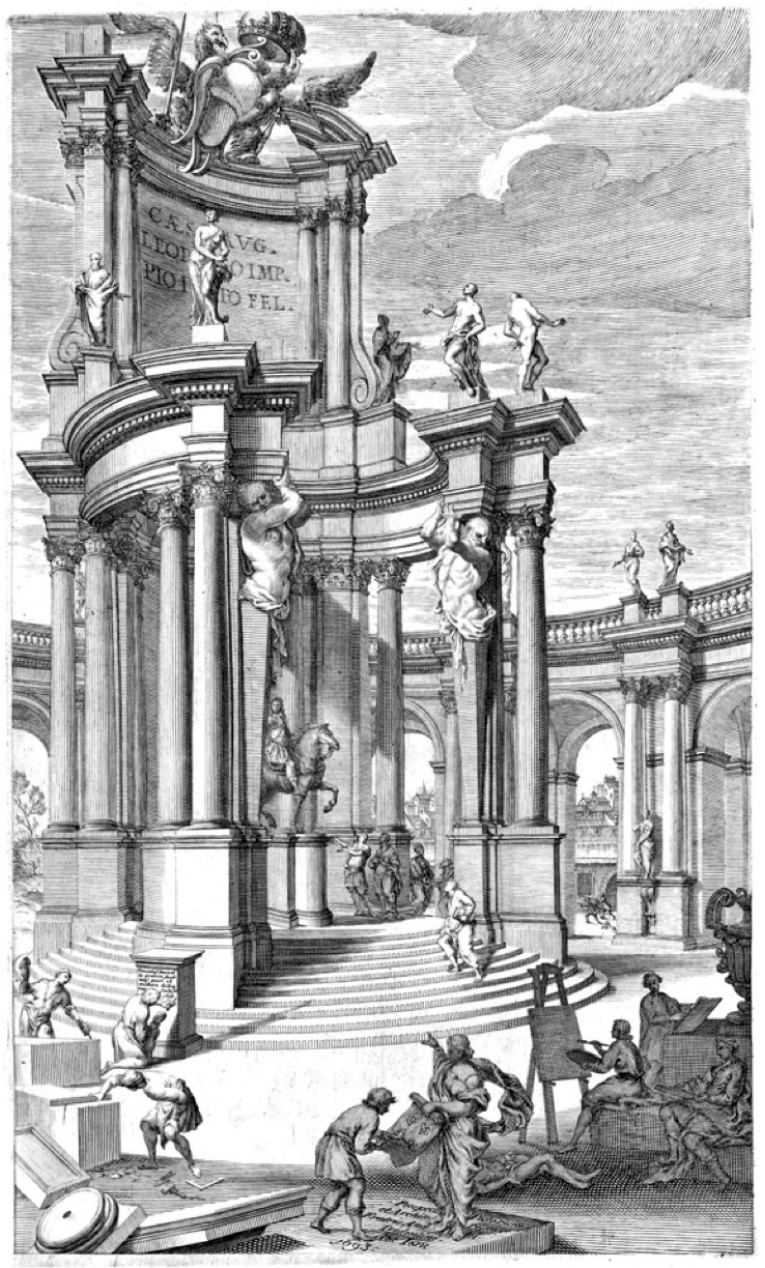


8 "Pensei em terminar esse livro com a figura 92. Todavia, para satisfazer aos desejos dos amigos que almejavam entender a maneira de desenhar a quadriculação perspéctica que se adota nas superfícies irregulares, como demonstramos na figura 89, decidi publicar o modo de fazê-la" (I, 93).

9Para a questão sobre a suposta edição, cf. Fuentes Lázaro (2015, p. 102).

Figura 4a (esq.): Falsa Cúpula - Igreja de Santo Inácio, Roma. Fonte: do autor.

Figura 4b (dir.): Falsa Cúpula. Fonte: Perspectiva Pictorum et Architectorum, vol. I, fig. 91.
Pozzo dedica a parte final do seu tratado às projeções de perspectiva em planos horizontais (I, 78-92), das mísulas às cúpulas inteiras, como o maior exemplo realizado pelo autor na cúpula pintada da Igreja de Santo Inácio (figura 4). O primeiro projeto do tratado deveria finalizar, segundo o autor, justamente com essas figuras de perspectiva horizontal ${ }^{8}$. Contudo, foi incluído o projeto - ainda inacabado - da pintura da nave da Igreja de Santo Inácio, apresentando desde a arquitetura real do templo $(1,93-94)$ até as partes que vinha executando no local (95-99), fechando as figuras com um método de projeção do desenho sobre a superfície irregular da abóbada (I, 100). Em edição posterior de 1702, dentre outras modificações, foi inserida a gravura completa do teto de Santo Inácio para completar o volume (figura 5) (BÖSEL e SALVIUCCI INSOLERA, 2010, p. 131).

É possível conjecturar-se que uma primeira versão do tratado poderia ter circulado, seja em manuscrito, seja em formato impresso, que não persistiu até os dias atuais. Em diversos momentos Pozzo parece responder ou procurar modificar o que havia proposto inicialmente. Esse é o caso da organização do volume que, como vimos, teria sido finalizado na figura 92, mas fica ainda mais evidente nas inserções que realiza ao final do volume, a saber: uma "Resposta a uma objeção feita ao ponto da Perspectiva" e uma nova explicação para cada uma das doze primeiras figuras, além do fólio avulso que insere logo após a figura 52, contendo as "Ordens da Arquitetura de Palladio e Scamozzi", sem numeração. Contudo, nenhum registro manuscrito ou impressão dessa suposta edição subsistiu? .

Reconhecer essas possíveis inserções no texto nos permite também perceber como as edições foram sendo modificadas ao longo do tempo, principalmente com a publicação do segundo volume, em 1700. Passaremos rapidamente sobre os temas que o compõem.
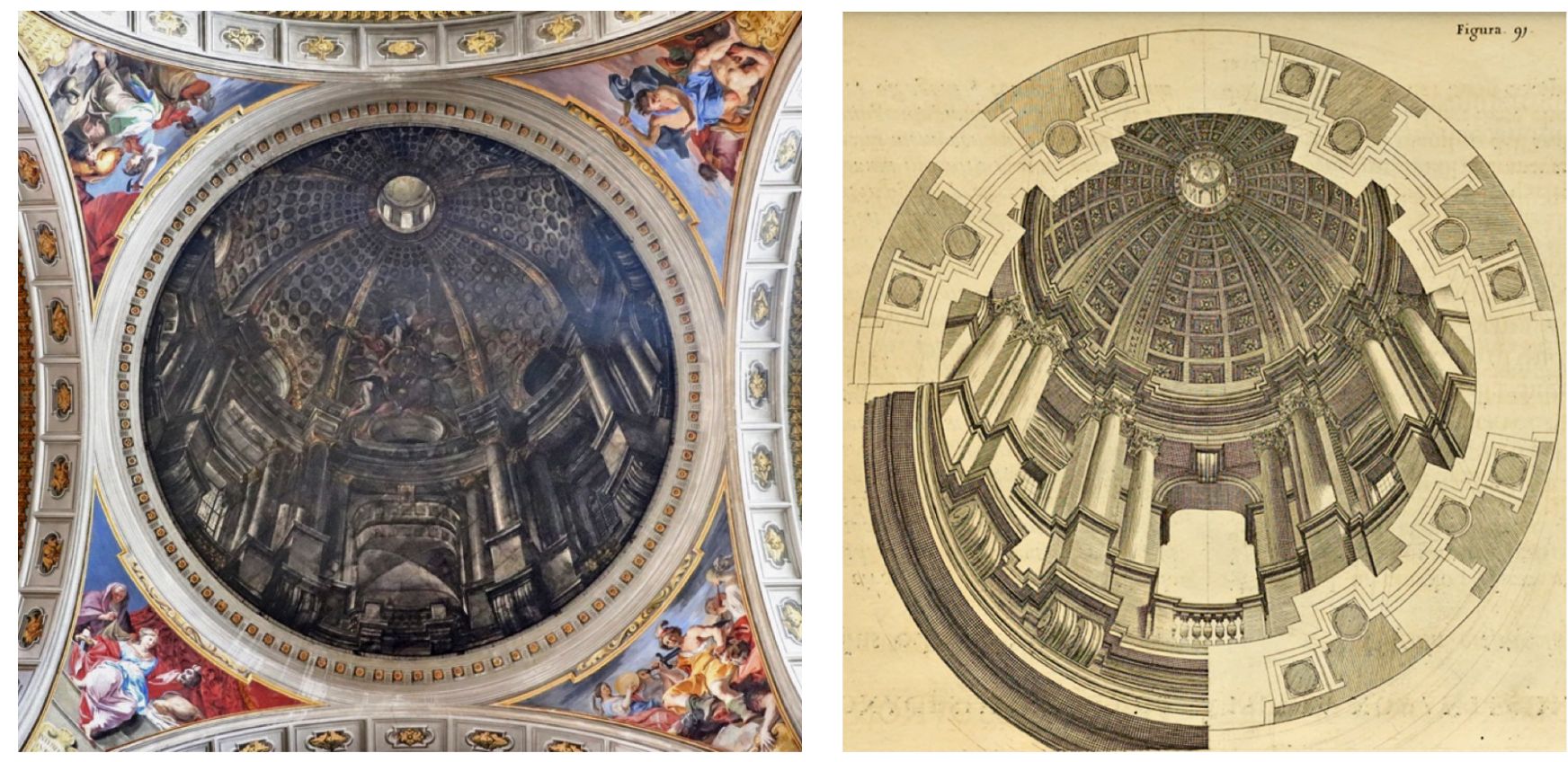

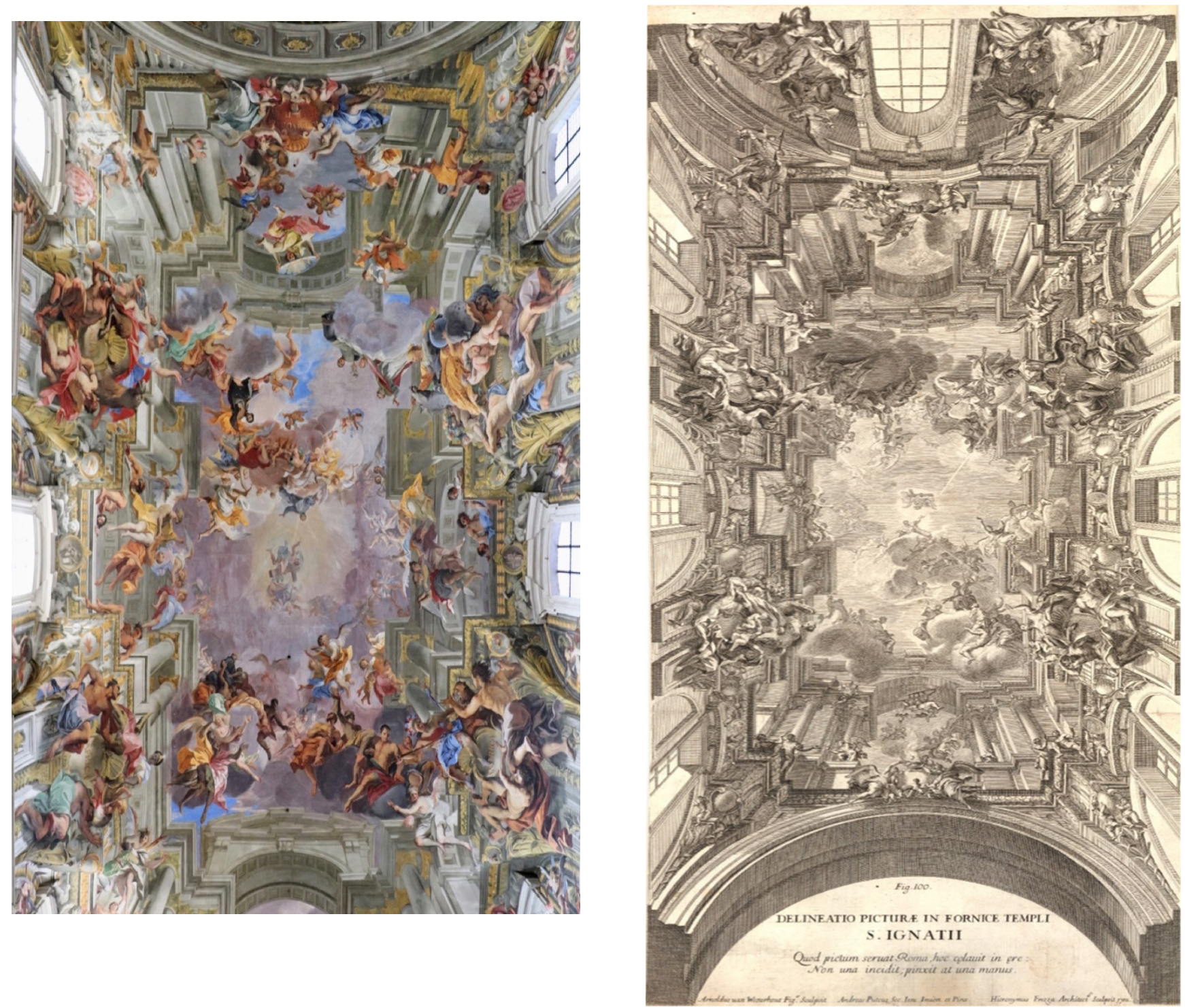

Figura 5a (esq.): Abóbada da nave - Igreja de Santo Inácio, Roma. Fonte: do autor.

Figura 5b (dir.): Delineatio Picturae in Fornice Templi S. Ignatii. Hyeronimus Frezza e Arnoldus van Westerhout, c. 1702. Fonte: British Museum, CC. Incluído em Perspectiva Pictorum et Architectorum, vol. I, fig. 100 (edição de 1702).

100 jubileu de 1700 foi estipulado por Inocêncio XII que, contudo, faleceu antes das festividades. Em seu lugar foi eleito o papa Clemente XI.
O segundo volume de Perspectiva Pictorum et Architectorum veio a lume em 1700, ano jubileu dentro das festividades católicas ${ }^{10}$. Seguiu a mesma linha de apresentação do primeiro livro, considerando a continuidade do projeto e apresentando uma nova regra para a perspectiva. Segundo o autor, esse novo método seria ainda mais fácil e prático que o primeiro, posto que fazia parte daquilo que ele mesmo utilizava e ensinava no canteiro ${ }^{11}$. Na linha do primeiro volume, o segundo seria dedicado ao futuro imperador, José I, rei dos Romanos e da Hungria, arquiduque da Áustria.

Talvez por essa praticidade e por ver na sua prática didática a necessidade de se aprofundar em questões específicas da arquitetura é que o autor opta por abrir o volume com quatro explicações do modo de se representar em arquitetura (planta e elevação, II, 1-3), para só então apresentar o conceito de perspectiva (II, 4-5). Daí começa a dispor os primeiros elementos de arquitetura, tanto aqueles feitos a partir do quadrado (bases e pedestais) quanto do círculo (colunas e plantas circulares II, 6-14). Apresenta uma tribuna preenchida de arquitetura (II, 15), seguida de uma série de elementos (pedestais, arcos, colunas e capiteis) (II, 16-36) e se utiliza desses exemplos 
11 "Finalmente mantenho a promessa de publicar a segunda parte da perspectiva, esperando que seja recebida não com menor satisfação que a primeira, sobretudo por nesta se explicar (o quanto possa ser feito com a voz morta) a mais fácil e simples regra de que se possa dar nesta Arte da Perspectiva. (...) Esta é, então, a regra mais fácil que tenho adotado até agora nas obras que fiz ver várias vezes em Roma e outros lugares, e a ensinei por um breve período para o proveito também daqueles de pouca habilidade." (II, Ao Leitor).

12 Diz claramente no final da figura anterior "Isso é o que tenho a dizer brevemente sobre a pintura. Daqui em diante falaremos das coisas que concernem à Arquitetura" (II, 59).

\footnotetext{
13Fuentes Lázaro sintetizou a temática de todo tratado em quatro grandes grupos, que perpassam e se repetem nos dois volumes, a saber: os elementos básicos e repertório de geometria, perspectiva e ordens de arquitetura; a perspectiva horizontal (sotto in sù); as arquiteturas originais de Pozzo e os lugares da Companhia de Jesus; e os instrumentos e técnicas (construção de telas e cenas teatrais, transposições do desenho e técnicas de pintura). (FUENTES LÁZARO, 2015, p. 138).
}

para inserir alguma dificuldade na representação, seja por uma vista em ângulo, seja por uma forma diversificada, ou "caprichos" — invenções possíveis para ornamentação. Pozzo retoma, em seguida, a possibilidade de utilização dessa nova regra também para os Teatros, assim como no primeiro volume. Apresenta nesse caso não apenas a disposição das cenas (II, 37-38), mas também modos de criar estruturas cênicas a partir da disposição em perspectiva de diferentes formas de teatros (II, 39-45). Assim como no primeiro volume, mas em ordem inversa, passa dos "teatros cênicos" aos "teatros sacros", com novas invenções das quais se serviu para as festas religiosas (II, 46-49). Em seguida, retoma o tema da perspectiva horizontal, debatendo as diferenças entre os métodos dos dois volumes e demonstrando a sua complementaridade, com o exemplo das cúpulas e dos tetos planos (II, 50-59).

A partir da figura 60, Pozzo vai explicitamente se voltar para a arquitetura ${ }^{12}$, demonstrando as obras que já havia realizado durante a sua carreira ou que considerava relevantes, iniciando com altares e reunindo, por meio dos desenhos, aqueles que haviam sido construídos, pintados e projetos não executados (II, 60-82). O primeiro desses altares é o de Santo Inácio de Loiola, obra das mais importantes para a Companhia e de que se ocupou desde 1695 (figura 8). Dos altares passa aos projetos arquitetônicos completos, construídos ou não, de sua fatura ou de importantes monumentos (II, 83-96). Depois de tratar largamente sobre a arquitetura religiosa, Pozzo faz um apanhado sobre a arquitetura civil e, na mesma maneira que usa para os altares e igrejas, apresenta projetos (com plantas e elevações) de portas e janelas que havia recolhido em Roma, alguns de sua própria invenção (II, 97-105), e propõe algumas invenções para mísulas ornamentadas (II, 106-108), além do projeto para um Colégio e escadarias (II, 109113). Finaliza o tratado com uma brevíssima incursão sobre as fortificações militares (II, 114-118) $)^{13}$ e uma "Breve instrução para pintar afresco", em que apresenta técnicas de pintura e alguns comentários sobre tintas e materiais.

É preciso ressaltar que o segundo volume tem um caráter muito mais expositivo do que propriamente instrutivo, pelo menos no que tange aos exemplos utilizados. Menos da metade da obra vai se ater ao método que, uma vez explicado, daria espaço para apresentar as mais diversas formas de aplicação da perspectiva, tanto por pintores quanto por arquitetos.

Considerando as diferentes edições de Perspectiva Pictorum et Architectorum, bem como as traduções, impressas ou manuscritas, com versões completas ou parciais do texto, percebemos claramente como a obra teve uma considerável circulação. Cabe agora desenvolver um pouco mais o argumento que apresentamos, qual seja, de que a difusão da obra de Pozzo se deu sobretudo pela qualidade e facilidade do método apresentado, cujos exemplos funcionam como modelo para a prática artística, além de difundirem a memória das obras do próprio artista e, por consequência, da Companhia de Jesus.

\section{Dois métodos de representação da perspectiva}

O primeiro elemento chave para se entender a eficácia do tratado e sua difusão diz respeito aos métodos de desenho de perspectiva. Na história da perspectiva, alguns autores tendiam a procurar o método único e eficaz para o desenho, enquanto outros, como Vignola, entendiam que múltiplas regras poderiam chegar ao mesmo resultado. 
14A publicação de Le due regole della prospettiva pratica foi realizada postumamente (1583), por Egnatio Danti (1536-1586), que compilou os escritos de Vignola e realizou extensos comentários teóricos a cada preceito apresentado, transformando-o praticamente em um tratado duplo. (FIORANI, 2003, p. 144).
15 "A grande experiência desse autor na prática da perspectiva Ihe fornecey excelentes regras para reduzir o trabalho e evitar as dificuldades mencionadas". (POZZO, 1707, p. 7) As dificuldades que cita referem-se à confusão das linhas que surgem da projeção em perspectiva de todos os pontos da imagem para o ponto de fuga, o que atrapalharia o aprendiz.
Provavelmente por essa influência de Vignola (ou dos círculos oficinais de pintura em que pôde ter tido contato), Pozzo apresentou as suas duas regras de perspectiva, sendo a primeira conhecida como a "regra comum" endereçada aos iniciantes, enquanto a segunda estaria adequada a um artista mais avançado e que conhecesse os princípios da perspectiva (BINAGHI, 2011, p. 164).

Pascal Glatigny considera que a primeira regra de Pozzo é exatamente a mesma aplicada por Vignola em Le due Regole della Prospettiva Pratica ${ }^{14}$, mais especificamente a segunda daquele livro (GLATIGNY, 2009, p. 19). Porém, importa relembrar, como revela o mesmo autor, que a difusão da regra de Vignola era tal que o método que apresenta já estava inserido nas oficinas dos pintores, de modo a se transformar na "regra comum", portanto não explicitamente atrelada ao seu tratado. Curiosamente, quando Pozzo cita a Vignola, o faz sobretudo no que diz respeito ao cânone das cinco ordens por ele apresentado, mas não cita em nenhum momento as suas regras para perspectiva, denominando-as vagamente também de "regra comum" (cf. l, Ao Leitor).

A regra comum se revela como a disposição do plano e da elevação em perspectiva com o auxílio de um ou dois pontos de distância. Considerando primeiramente um objeto plano, consiste em tomar as medidas da largura e levá-las ao ponto de fuga (denominado por Pozzo como ponto do olho, punto dell'occhio) e, da altura, ao ponto de distância (definido pela distância do observador ao ponto de fuga, projetado sobre a linha do horizonte). Assim, na interseção das linhas feitas até esses dois pontos, se constrói o objeto em perspectiva (cf. I, 2-4). Já os objetos sólidos são feitos com a ajuda de sua planta e elevação, consideradas como duas figuras planas. A interseção dessas duas figuras dispostas em perspectiva gera o objeto sólido, também em perspectiva. O que Pozzo facilita para a regra é o uso do compasso, na medida em que considera que alturas e larguras paralelas podem ser facilmente transportadas com a ajuda do instrumento (figura 6). Assim, para todas as imagens que apresenta, é preciso fazer um desenho preparatório contendo planta e elevação em perspectiva, para só então finalizar o objeto. Esse artifício reduz a "confusão das linhas" por se valer do compasso para tomar as medidas, evitando assim que muitas linhas sejam traçadas tanto ao ponto do olho quanto da distância.

Essa variação proposta por Pozzo em relação à regra comum foi valorizada na versão inglesa da obra publicada em 1707 (Rules and Examples of Perspective proper for Painters and Architects) ${ }^{15}$. O argumento utilizado pelo editor era de que a maior parte dos tratados não resolvia a questão da confusão das linhas por sempre confinarem a área do desenho entre as linhas do plano e do horizonte e, em situações peculiares como a pequena escala da figura ou a altura da linha do horizonte, impossibilitavam a construção do desenho. Por isso, apresentava o tratado de Pozzo como aquele que finalmente resolve o problema ao permitir a execução de desenhos preparatórios, em diferentes escalas ou distâncias do ponto do olho.

A construção do plano e elevação valia também para a perspectiva horizontal, sendo que essa regra tornava o trabalho mais fácil por ser a altura dos objetos igual à linha que vai ao ponto do olho. Essa forma valorizaria também as possibilidades de projeção dos desenhos em planos horizontais, nomeadamente os tetos, ênfase que Pozzo procurou dar em função das obras que vinha realizando com maestria. 
Figura 6: Métodos de projeção em perspectiva. Fonte: Perspectiva Pictorum et Architectorum, vol. I, fig. 5 e vol. Il, fig. 5.
Já a segunda regra de perspectiva de Pozzo, apresentada no segundo volume de Perspectiva Pictorum et Architectorum, é muito mais pessoal e decorrente da prática do artista. Consiste, em linhas gerais, na realização de desenhos preparatórios para a planta e a elevação, em folha separada, assim como na primeira regra. A diferença está no passo seguinte: enquanto na primeira regra é preciso colocar planta e elevação em perspectiva, na segunda só se tomam dessas preparações os pontos essenciais. A partir da projeção ao ponto do olho dos limites do objeto na planta, e da elevação em uma linha, denominada linha do corte (linea del taglio), faz-se a perspectiva sem o uso de um ponto da distância e sem o artifício de projetar sobre planta e elevação em perspectiva, antes de passar ao desenho finalizado (II, 5) (figura 6). Dessa forma, consegue-se fazer o desenho com uso do compasso, transpondo os pontos em suas alturas e larguras determinadas, e depois completar o desenho, em perspectiva. Por não usar o ponto de distância como na primeira regra, Pozzo define essa distância como a existente entre o observador e o horizonte sobre uma linha perpendicular, fazendo o desenho proporcionalmente à distância real entre o observador e o suporte. Com esse artifício, consegue fazer todo o desenho e depois transpô-lo no suporte real por meio da quadrícula. Como dito por Glatigny, "esse método consiste em uma execução rápida, emprega pouca geometria e nenhuma aritmética: por isso é um método de fácil assimilação por quem não tem uma preparação matemática, não obstante o que diz Pozzo" (GLATIGNY, 2009, p. 20).
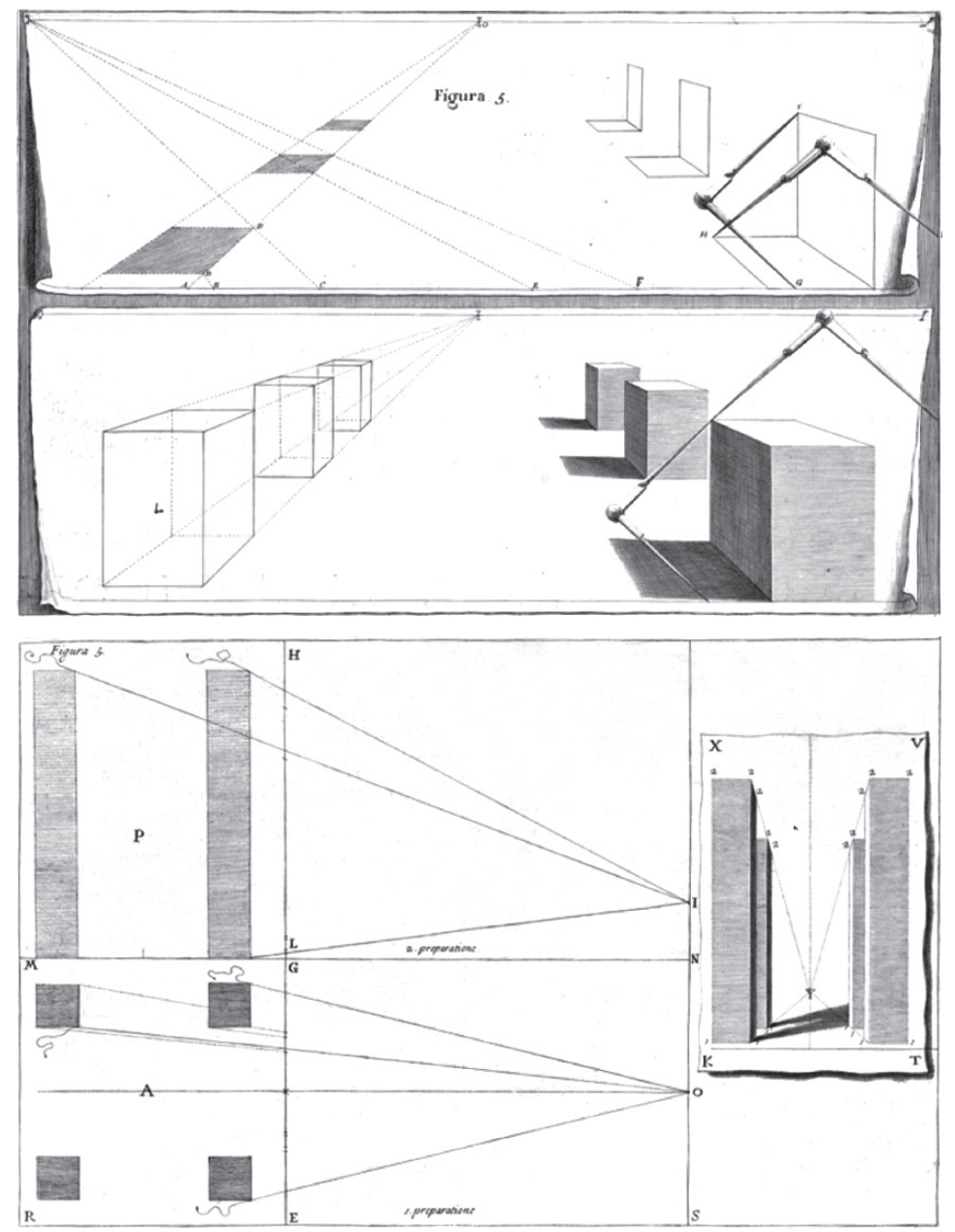
Pela facilidade desse segundo método e a ausência de grande parte das linhas é que o segundo volume também teve o seu contributo para garantir a eficácia do tratado. Essa nova regra, associada à anterior, deixa o volume menos teórico no que diz respeito às formulações de projeção em perspectiva, permitindo também a apresentação de um maior número de construções.

\section{Método e modelo}

Os exemplos de formas a serem dispostas em perspectiva oferecidos por Pozzo são vários e essas imagens fazem parte de um repertório comum aos tratados de perspectiva. No tratado em questão são apresentados: elementos das ordens arquitetônicas (I, 8-37), fragmentos de arquitetura (II, 26-36), portas, janelas e mísulas (II, 97-108), escadas (II, 111-113), fortificações (II, 114-118) e estudos de cenografia (I, 72-77 e II, 37-44). A esses diversos modelos (aos quais Pozzo sempre se referia como passíveis de serem modificados segundo o gosto e o entendimento do pintor/arquiteto) se somam as várias edificações de forma inteira, para serem utilizadas tanto em pintura quanto arquitetura. Por essa razão os métodos apresentados adquirem uma aplicabilidade prática, expressa nas possibilidades de projetos reais, contribuindo para a rápida difusão do tratado.

Para Pascal Glatigny, o sucesso editorial do tratado se deve a vários fatores:

o tratado se fundava sobre uma questão técnica que todos reconheciam como inevitável, mas não entrava nos particulares dos teoremas geométricos e evitava ao leitor a quantidade de diagramas que tornava desagradável a maior parte dos tratados publicados pelos matemáticos; oferecia uma vastíssima variedade de exemplos de arquiteturas contemporâneas cujos motivos podiam, em particular pelos ornamentos e as ordens da arquitetura, inspirar os arquitetos europeus com os modelos italianos; enfim, demonstrava esplêndidos exemplos de pinturas ilusionistas de "sottinsù" e dava a impressão de revelar os segredos das práticas culturais que estavam na moda, como a das cenas de teatro. (GLATIGNY, 2009, p. 28) (tradução nossa)

Na mesma lógica de Glatigny, Richard Bösel também expressa a importância dos modelos ofertados pelo tratado, baseado na experiência:

No tratado de Pozzo deve-se reconhecer (para além do intrínseco valor didático de manual de perspectiva prática) um caráter decididamente representativo que nasce com o intento de afirmar, publicando as concretas realizações arquitetônicas e pictóricas, a pertinência prática das metodologias explicadas por ele. Ao mesmo tempo se manifesta, porém, o desejo do autor de fazer avaliar a própria obra artística por uma comunidade mais vasta possível e por isso a obra adquire um aspecto autocelebrativo. (BÖSEL e SALVIUCCI INSOLERA, 2010, p. 263) (tradução nossa)

A esses fundamentais aspectos do caráter técnico e dos métodos oferecidos por Pozzo nos dois volumes do seu tratado é imprescindível, ao nosso ver, somar a natureza e qualidade dos objetos representados como exemplo para a perspectiva, por serem obra do próprio autor e majoritariamente confeccionados para a Companhia de Jesus. Esse vasto conjunto de peças de pintura e arquitetura tornavam-se registro da obra de Pozzo, mas consideramos que remetem à configuração de uma memória artística da própria Ordem Jesuíta, devido aos exemplos selecionados. 
16 Claude Lorrain foi um pintor que elaborou um livro em que registrou por meio de gravuras as suas principais obras, conhecido como Liber Veritatis ou Liber Inventionis. Mais tarde, no final do século XVIII, foi publicado em inglês como Liber Veritatis, or a Collection of Prints after the Original Designs of Claude Le Lorrain. (FUENTES LÁZARO, 2014, p. 35-36).

${ }^{17} \mathrm{~A}$ autora desenvolve o conceito de "propaganda" como uma ferramenta necessária à compreensão do posicionamento político e artístico da igreja católica no século XVII, com especial foco na Companhia de Jesus (LEVY, 2004). Estabelece, nesse sentido, um paralelo com o conceito de "persuasão" estabelecido por Argan (2004), notando as diferenças entre o uso da retórica e da propaganda como instrumentos de análise do período.

18 Ressalta-se que o tema das festividades, sobretudo das Quarenta Horas, é caro a Pozzo, tanto que insere já na figura 30 , de um Edifício Jônico, a possibilidade de aplicação do desenho para um aparato efêmero (I, 30), antecipando os exemplos que vai dar em seguida.

19 A devoção das Quarenta horas (Quaranta hore, Quarant'ore ou simplesmente Quarantore) consiste na vigília em oração ininterrupta da exposição do Santíssimo Sacramento. É normalmente associada ao período da Semana Santa rememorando as quarenta horas de exposição do corpo sepultado de Cristo, iniciada pela Missa da Exposição e finalizada pela Missa da Deposição. Contudo, seu uso foi ampliado para qualquer evento de exposição do Santíssimo Sacramento com vigília e oração ininterrupta, como durante o período do Carnaval (prática incentivada por Inácio de Loyola, por exemplo).

\section{Pozzo e um repertório arquitetônico para a Companhia de Jesus}

Uma leitura do tratado Perspectiva Pictorum et Architectorum como a exposição do conjunto da obra de Pozzo foi apresentado por Fuentes Lázaro (2014), na consideração de que o artista elaborava em seu volume uma compilação de seus feitos, à maneira que fizera Claude Gellée (Claude Lorrain, 1600-1682) em seu Liber Veritatis ${ }^{16}$. Esse argumento é, para nós, fundamental, pois inclui Pozzo em um contexto de fomento ao registro da sua obra artística (nos aparatos efêmeros, pintura e arquitetura) por meio da gravura, o que permite instituir sua memória e sua divulgação.

O que pretendemos aqui é avançar nessa interpretação e compreender o lugar do tratado não apenas na construção de uma memória do artista, mas da própria Companhia de Jesus. É evidente que essas memórias se confundem na medida em que, como vimos no capítulo anterior, Pozzo trabalhou para a realização das principais obras da Ordem no final do século XVII em Roma, sobretudo aquelas que tinham mais apelo aos lugares sagrados para os jesuítas, de fundamental culto ao seu fundador: os aposentos, o altar e a igreja de Santo Inácio de Loyola. Porém, é no registro de obras que foram realizadas ou não por Pozzo, cuidadosamente inseridas no tratado, é que percebemos esse caráter de memória das obras mais recentes da Companhia.

Evonne Levy foi também uma das autoras que trabalhou a relação da produção artística de Andrea Pozzo como meio necessário à consolidação da Companhia de Jesus no final do século XVII, tendo por exemplos principais o Corredor da Casa Professa e o Altar de Santo Inácio no Gesù (LEVY, 2004). Analisando essas obras como instrumentos de propaganda ${ }^{17}$, demonstrou como esses casos fundamentais contribuíram para a afirmação da imagem da Companhia e disseminação do culto a Santo Inácio de Loyola. Contudo, não se aprofunda na possibilidade dessa difusão ocorrer via publicação do tratado de Pozzo, por se ater mais especificamente às obras. É na conjunção, portanto, das leituras que Fuentes Lázaro e Levy propõem que pretendemos inserir os volumes de Pozzo como fundamentais para a constituição da memória da companhia no fim do século.

Como apresentamos anteriormente, o intuito de Pozzo ao se endereçar a Leopoldo I no primeiro volume do tratado tinha por objetivo a exaltação e construção da memória das vitórias obtidas pelo imperador. Ao mesmo tempo, podemos ler os exemplos de obras apresentados por Pozzo como a celebração da sua própria memória que, por sua vez, associa-se à da Companhia de Jesus no final do século XVII.

No primeiro volume, Pozzo apresenta alguns exemplos cruciais da sua formação e estada em Roma a partir da década de 1680, referindo-se principalmente aos aparatos efêmeros para as festividades religiosas ${ }^{18}$. Apresenta quatro construções e suas preparações: o Tabernáculo Octogonal (I, 54-62), de que se serviu para a exposição das Quarenta Horas' ${ }^{19}$; a Construção Quadrada (I, 63-64), como outra possibilidade de ser utilizado na mesma festa; a Construção Circular (I, 65-66) feito para a Semana Santa na Igreja de Santo Inácio; e o Teatro das Bodas de Caná (I, 67-71), feito para a exposição das Quarenta Horas na Igreja de Jesus no ano de 1685.

É interessante observar que projeto e execução são indissociáveis no caso dos aparatos efêmeros, sendo que alguns são tomados sem uma referência explícita à sua ereção real, enquanto outros são datados e bem localizados. Nesse caso, por versar sobre 
20 "A cúpula que aqui vedes terá, sem dúvida, uma vida mais longa que aquela que eu, sobre uma tela gigantesca, pintei no ano de 1685 na Igreja de Santo Inácio do Colégio Romano. Por isso, se aquela desgraçadamente se arruinar, por meio desta poderá ser refeita ainda melhor que a primeira" (I, 91). peças efêmeras, o registro no tratado de Pozzo toma o mesmo lugar das descrições de festas, disseminadas em inúmeras publicações, com sua riqueza de detalhes e da ambientação que se dá na renovação do edifício. Note-se, ainda, que os exemplos dados por Pozzo são de sua própria lavra, executados diretamente para a Companhia de Jesus nos seus principais templos romanos, o que se torna também a memória das festividades da própria Ordem Jesuíta, que se esmerava em apresentar esses espetáculos públicos, sobretudo como prática pedagógica.

O outro exemplo caro a Pozzo no primeiro volume é a Cúpula em perspectiva que pintou para a Igreja de Santo Inácio em 1685 (I, 90-91) (figura 4). O autor chega a descrever a introdução da obra no volume com o objetivo de resguardar o seu projeto, permitindo a possibilidade de sua refeitura. ${ }^{20}$

Além dessas referências, o que aparece como singular no volume, contudo, é a introdução do projeto para a Igreja de Santo Inácio, em planta e elevação, com o objetivo de se demonstrar o local onde se realizavam os trabalhos da pintura da abóbada da nave (93-94). O próprio Pozzo reconhece que não seria necessário incluir toda a obra, mas que o fazia para "dar proveito àqueles que gostam de Arquitetura, pondo diante dos olhos um desenho estimado por sua beleza e simetria" (I, 93). A cuidadosa planta, assim como a elevação, dá uma notícia visual da obra projetada pelo matemático e arquiteto Orazio Grassi, tanto que a cúpula projetada pelo jesuíta (não construída) foi inserida na elevação (figura 7).

Mesmo com a obra do teto da nave incompleta, Pozzo ainda finaliza o volume com a representação da quadratura, uma vez que ainda estava pintando as figuras (cf. I, 93). Como visto anteriormente, nas demais edições do tratado a obra aparecerá finalizada, valorizando assim a estrutura real e sua quadratura principal.

O mesmo processo de exposição das obras próprias e da Companhia ocorre no segundo volume, com maior intensidade. A partir da figura 45, Pozzo passa a descrever, por exemplo, as peças de arquitetura efêmera que realizou no final do século, com ênfase para aquelas da Companhia: o Teatro Sacro (II, 45-47) e Outra invenção para o mesmo efeito (II, 48).

Do mesmo modo, com o pretexto de apresentar as diferenças entre as duas regras, dispõe novamente a cúpula da Igreja de Santo Inácio, repetindo inclusive a sua forma finalizada, "sombreada" (II, 51-53). O exercício de dispor a mesma figura a partir de dois métodos parece reforçar a possibilidade de execução pelos leitores-artistas.

As imagens que seguem a partir da figura 60 se referem a projetos arquitetônicos (construídos e pintados) realizados por Pozzo, com a introdução da sua obra principal em arquitetura, o altar de Santo Inácio de Loyola na Igreja de Jesus (figura 8). Diferentemente das exposições anteriores, aqui Pozzo antecipa a imagem em perspectiva, apresentada obliquamente para que se pudesse ver os relevos e ressaltos, para só então apresentar a sua planta e elevação. A obra em perspectiva é apresentada com riqueza de detalhes, incluindo todo o conjunto escultórico e a decoração parietal, com o objetivo de "enobrecer esse livro" (II, 60-61).

O mesmo ocorre com o altar de São Luís Gonzaga (na altura ainda Beato), localizado na Igreja de Santo Inácio (II, 62-66) (figura 9). Importa notar que o texto valoriza o 
Figura 7: Planta e elevação da Igreja de Santo Inácio, Roma. Fonte: Perspectiva Pictorum et Architectorum, vol. I, figs. 93 e 94
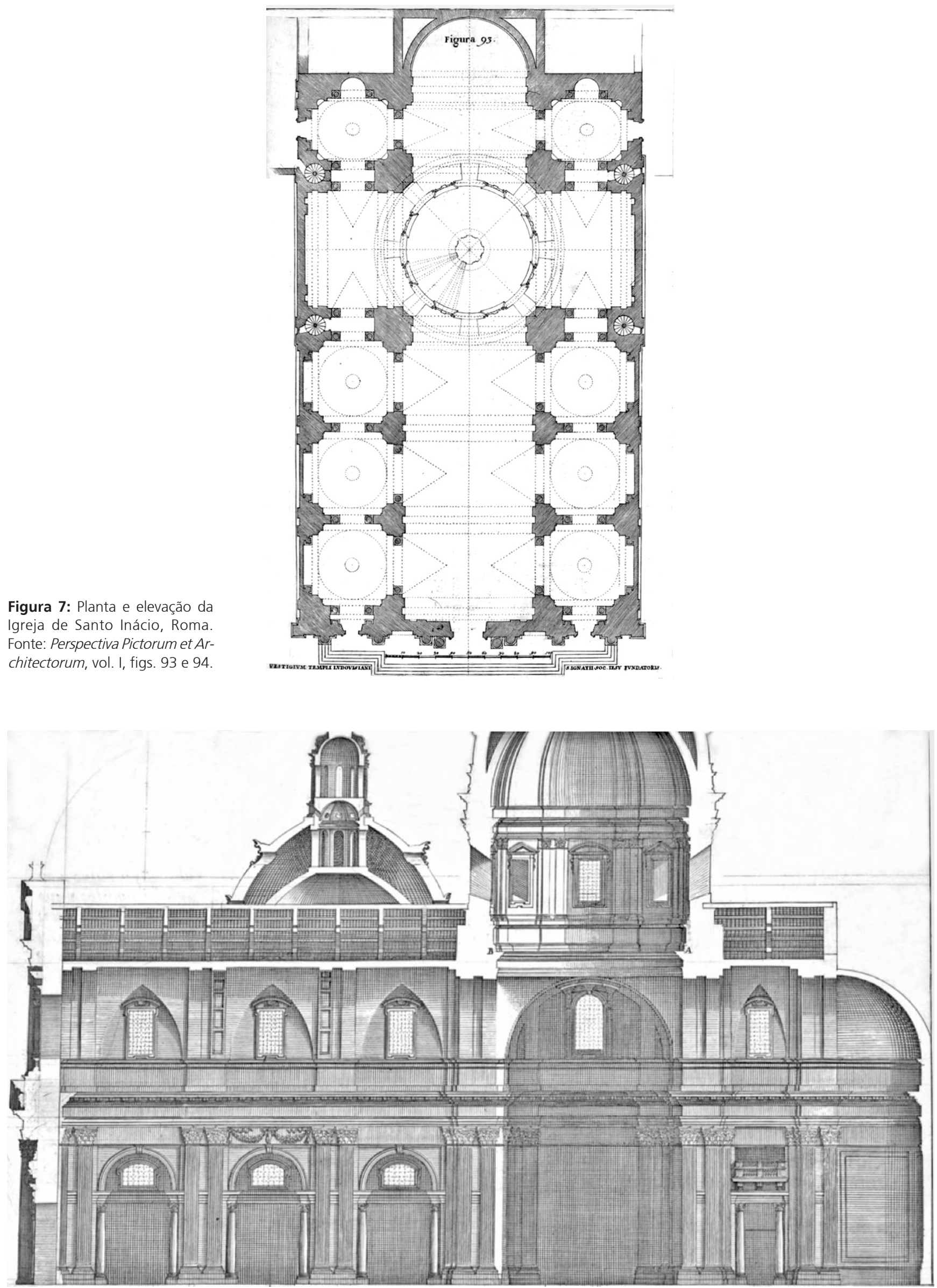

risCO. 2021_Edição Temática "Tratados da Arte" 

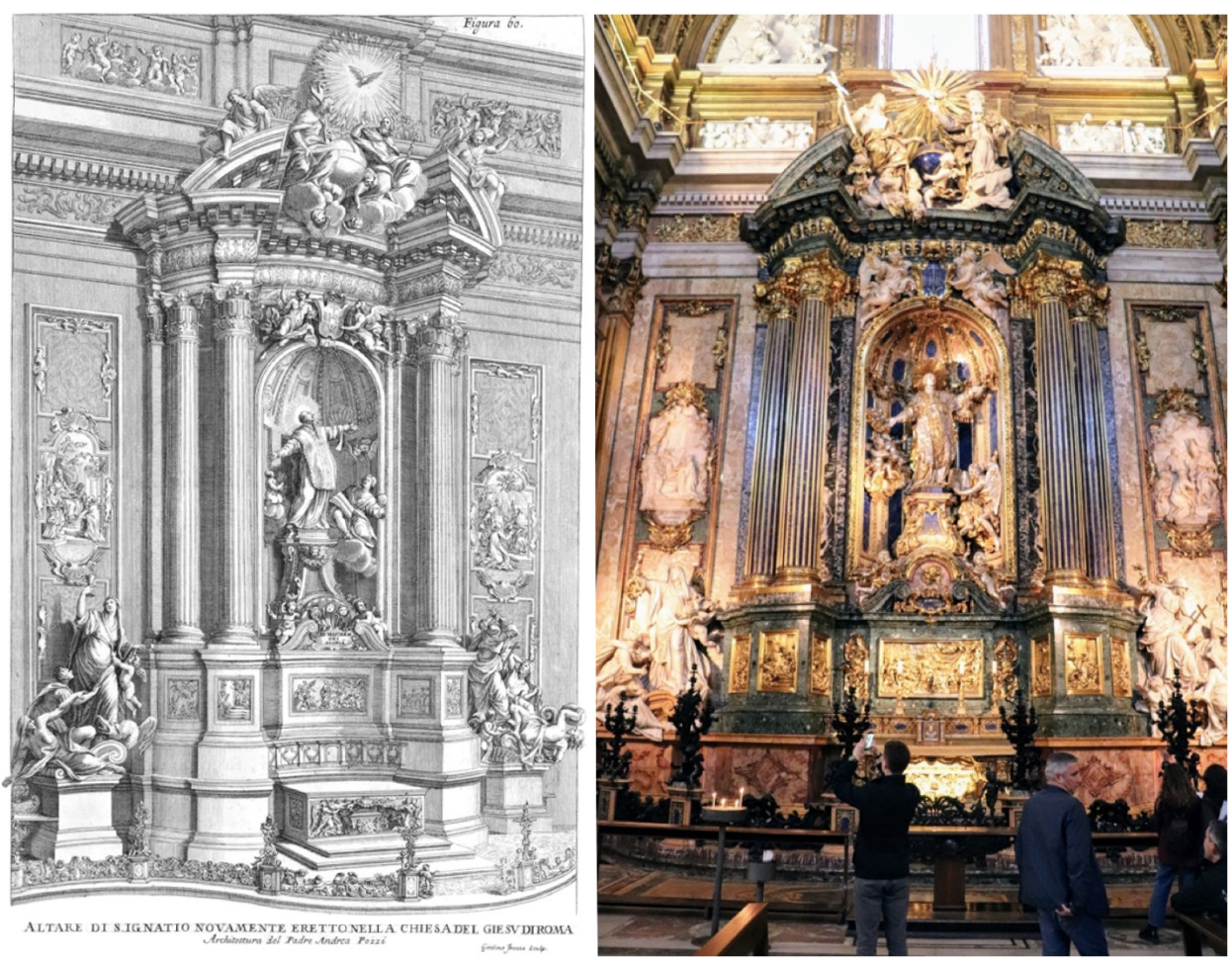

Figura 8 (topo): Altar de Santo Inácio de Loiola, Igreja de Jesus, Roma. Fonte: Perspectiva Pictorum et Architectorum, vol. II, fig. 60 .

Figura 9 (embaixo): Altar de São Luís Gonzaga, Igreja de Santo Inácio, Roma. Fonte: Perspectiva Pictorum et Architectorum, vol. II, figs. 62 .
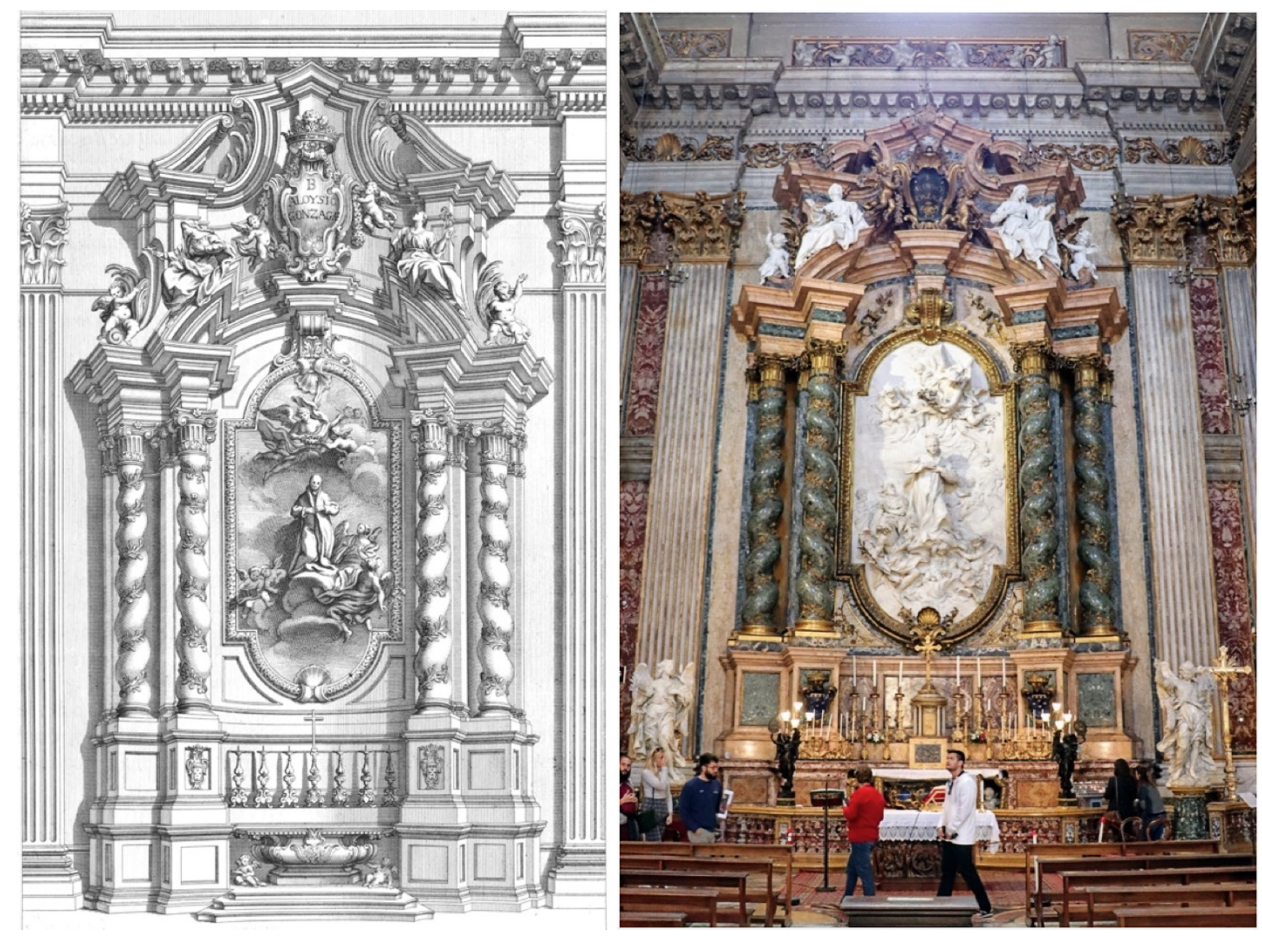
fato de a obra ter sido finalizada para o ano santo, 1700, assim como o altar de Santo Inácio no Gesù (ainda que ambos tenham sido concluídos no ano anterior), o que reitera a importância da obra. Se para esse mesmo altar Pozzo apresenta a sua planta e elevação, inclui também outros projetos: uma escolha mais simplificada, que o autor julgava "ser mais adaptada ao lugar onde estaria mais cômoda e proveitosa" (II, 64); e outra mais elaborada que, pela ousadia da elevação no ar da urna e da imagem do beato, estaria mais ligada a um exercício de arquitetura, já que "nem todas as coisas que vêem à mente do Arquiteto podem ser expostas ao público" (II, 65). Certo é que as três exposições do altar de Luís Gonzaga possuem o mesmo peso e caráter de modelo, quase como um convite à experimentação em arquitetura.

Na esteira dos altares, agora pintados (II, 71-74), Pozzo traduz em imagem dois exemplos, do altar do transepto (que existiu até 1749) que havia pintado na Igreja de Santo Inácio e também o altar mor da Igreja de Jesus em Frascati. Ambos os exemplos são passíveis de serem construídos, e por isso ele apresenta também suas respectivas plantas e elevações.

Provavelmente por já ser um projeto bastante difundido, Pozzo não introduz em sua obra a planta e a elevação da Igreja de Jesus de Roma (II, 71-74). Ainda assim, propõe duas novas soluções para o altar-mor, que se destoava das demais partes da igreja e era considerado pelo autor como "atualmente muito fraco" (II, 71). O primeiro altar de suas invenções fora utilizado como uma cena efêmera e poderia servir de base para uma possível construção futura, que o autor "quis inserir nesse livro para que os posteriores possam dele se servir e considerá-lo entre os demais Autores" (II, 71). A segunda invenção, mais ousada, tinha por objetivo abrir o vão do nicho do altar para uma cena exterior ou corredor pintado, ampliando a entrada de luz e o efeito visual (II, 73). Em ambos os casos se percebe o intuito de "modernizar" o espaço daquela igreja segundo o gosto corrente.

O tema dos altares é fechado com a apresentação do altar-mor da Igreja de Santo Inácio (II, 82-83), em que Pozzo já havia trabalhado com a pintura efêmera sobre tela cobrindo toda a capela-mor, quando estava realizando as pinturas no teto. O objetivo do autor em inserir a obra no tratado não parece ser outro além de apresentá-la finalizada, visando também a dispor como modelo "mais durável e estável, por ter sido fabricada de novo, real e verdadeiramente, porém diferente da anterior". (II, 81).

Por fim, para o nosso argumento da exposição das peças arquitetônicas da Companhia de Jesus, importa ressaltar o conjunto de imagens relativas à Igreja de San Fedele em Milão (II, 92-96) (figura 10). A Igreja, instituída por Carlo Borromeo e projetada por

21 O próprio Carlo Borromeo, na altura arcebispo de Milão, mandou construir a igreja. Borromeo é uma importante referência para a construção dos templos segundo o Concílio de Trento, com a publicação de Instructionum Fabricae et Supellectilis Ecclesiasticae libri duo (1577). (FRADE, 2016). Pellegrino Tibaldi, se transformava em uma importante referência das edificações pós-tridentinas ${ }^{21}$, e um centro de difusão da Companhia de Jesus no norte da Itália. Esse importante templo jesuíta seguia se formando como o exemplo dos templos de nave única, com a sua grande abóbada sustentada por seis enormes colunas e um vasto espaço interior. A ideia de Pozzo em inserir essa igreja no tratado, a despeito da justificativa de tê-la "visto muitas vezes" (no período de sua formação jesuíta) e achá-la "muito bem considerada e de grande satisfação para os olhos", guardava também outro intuito, como observado por Bösel: 
Figura 10: Igreja de São Fidélis (San Fedele), Milão. Fonte: Perspectiva Pictorum et Architectorum, vol. Il, figs. 94-95.
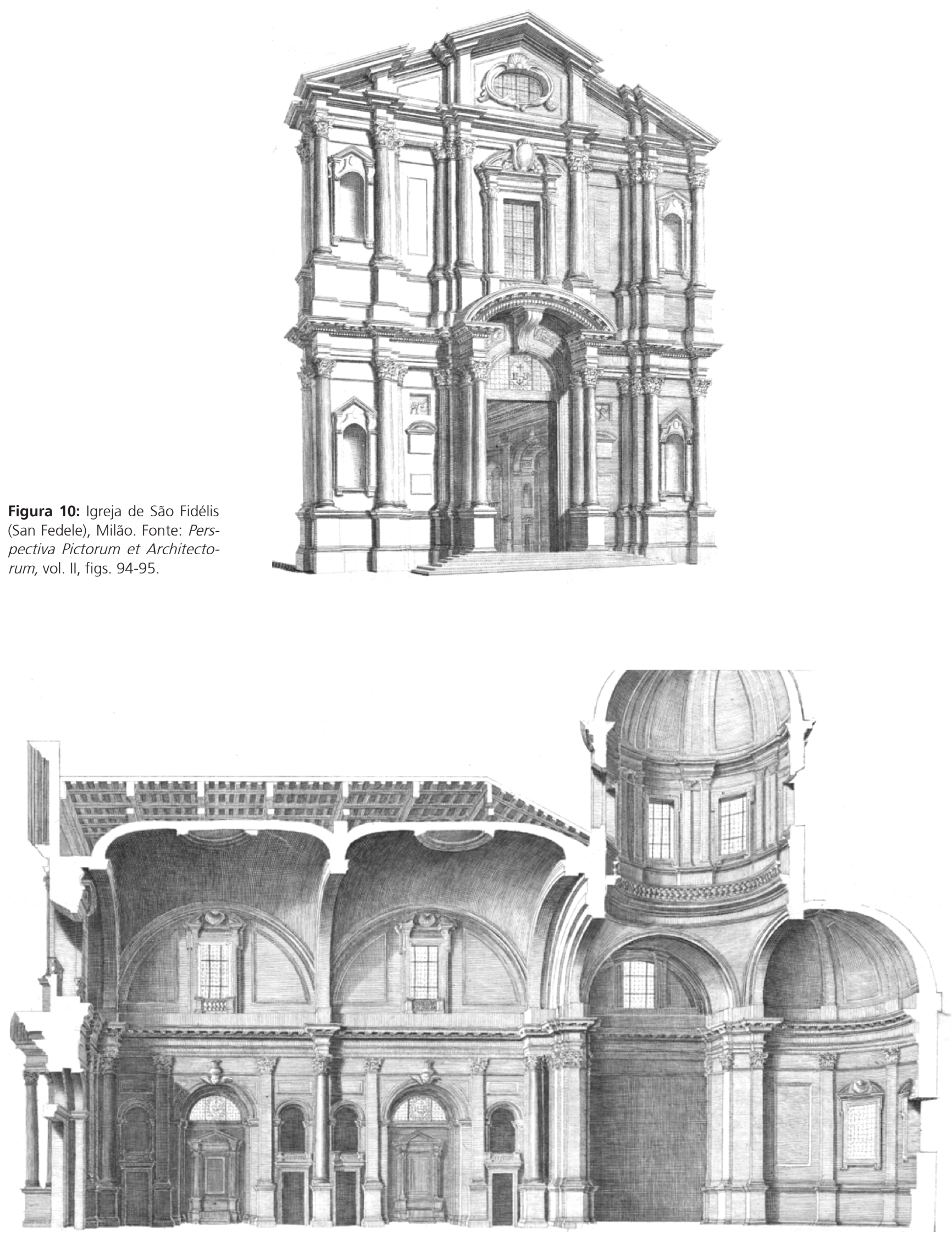

riSCO. 2021_Edição Temática "Tratados da Arte" 
Quando Pozzo se faz propagador de um modelo do século XVI esteticamente grandioso e ideologicamente sintomático, não o faz com base meramente na sua experiência pessoal. Ele propõe não apenas por ser aprazível aos olhos e bem disposto para o uso, mas porque o edifício se tornou um verdadeiro paradigma histórico da arquitetura sacra moderna e, não por último, um elemento quase emblemático da identidade cultural da sua ordem. (BÖSEL e SALVIUCCI INSOLERA, 2010, p. 265-266).

Nesse sentido, temos a disposição da estruturação arquitetônica dos templos principais da Companhia de Jesus condensada em um único tratado: a Igreja de Santo Inácio no primeiro volume e a Igreja de San Fedele no segundo, seguindo a mesma morfologia e servindo de parâmetro para outras possíveis edificações, tanto para a Companhia, quanto para além dela. Além disso, temos os diferentes programas decorativos, totalmente integrados às edificações, quer por pintura ou por arquitetura, realizados por Pozzo e representados em seu tratado. Isso ocorre sobretudo no templo central dos jesuítas, a Igreja de Jesus, e naquele dedicado ao santo fundador, além de tantos outros templos que executou ao longo da carreira.

É na confluência dessas frentes que vemos as bases que podem justificar a expressiva difusão que o tratado de Pozzo conheceu ao longo dos Setecentos. A elaboração e divulgação de um método de desenho de fácil compreensão e execução, pautados em um longo processo de desenvolvimento da teoria da perspectiva, assume em seu tratado um caráter absolutamente prático e endereçado aos principais utilizadores da técnica, pintores e arquitetos. Esses mesmos artistas se servem dos exemplos dispostos na obra como modelo, tanto para a reprodução dos elementos das ordens clássicas e suas variações, quanto para a invenção de novas peças - prática essa incentivada pelo autor. Além disso temos a difusão de uma obra que se revela como a memória artística do autor e da Companhia de que fazia parte, permitindo a difusão de diferentes programas arquitetônicos e decorativos produzidos no século e meio da existência da Ordem e que podem ter servido de base para vários outros projetos. Por essas razões, vemos a rápida circulação da obra em tantas e diferentes edições e traduções que perpassam todo o século XVIII.

\section{Referências bibliográficas}

ARGAN, G. C. Imagem e persuasão: Ensaios sobre o barroco. São Paulo: Companhia das Letras, 2004.

BÖSEL, R.; SALVIUCCI INSOLERA, L. Mirabili Disinganni. Andrea Pozzo (Trento 1642 - Vienna 1709) Pittore e architetto gesuita. Roma: Istituto Nazionale per la Grafica, 2010.

BALDINUCCI, F. S. Vite di Artisti dei Secoli XVII-XVIII. Roma: [s.n.], 1975.

BINAGHI, R. Istruire la mente e la mano secondo i precetti della Geometria: Andrea Pozzo tra Trento, Milano e Mondovì. Artisti dei Laghi, San Fedele Intelvi, v. I, p. 162-202, 2011.

FIORANI, F. Danti edits Vignola: The formation of a Modern Classic on Perspective. In: MASSEY, L. The Treatise on Perspective: Published and Unpublished. Washington: National Gallery of Art, 2003. p. 127-159.

FRADE, G. D. S. Entre Renascimento e Barroco: os Fundamentos da Arquitetura Religiosa e a Contrarreforma - o de Fabrica Ecclesiae de Carlo Borromeu. São Paulo: Faculdade de Arquitetura e Urbanismo. Universidade de São Paulo, 2016. (Doutorado em Arquitetura e Urbanismo). 
FUENTES LÁZARO, S. Prospettiva de' pittori e architetti come Liber Veritatis di Andrea Pozzo. In: VALENTI, G. M. Prospettive architettoniche. Roma: Sapienza Università Editrice, 2014. p. 35-48.

Usos y aplicaciones del tratado de Andrea Pozzo, Perspectiva Pictorum et Architectorum (Roma 1693-1700) en España: docencia científica y práctica artística en la primera mitad del siglo XVIII. Madrid: Departamento de Historia del arte II (Moderno). Facultad de Geografía e Historia. Universidad Complutense, 2015. (Doutorado em História da Arte).

GLATIGNY, P. D. Andrea Pozzo e I'architettura prospettiva. In: FRANCESCHINI, A., et al. Tra illusione e scienza: I'arte secondo Andrea Pozzo. Trento: Temi, 2009. p. 13-31.

LEVY, E. Propaganda and the Jesuit baroque. Berkeley, Los Angeles: University of California Press, 2004

. The "perspectives" of Baldinucci and Pascoli: publics, illusion, defects and judgement in the Vite of Andrea Pozzo. In: BÖSEL, R.; SALVIUCCI INSOLERA, L. Artifizi della metafora: Saggi su Andrea Pozzo. Roma: Artemide, 2011. p. 23-31.

MARIANI, G. "Sovente avviene che la durevolezza delle Carte sopravivva alla diuturnità delle Moli" - Le matrici in rame del trattato di Andrea Pozzo. In: BÖSEL, R.; SALVIUCCI INSOLERA, L. Mirabili Disinganni: Andrea Pozzo (1642, Trento - 1709, Vienna). Pittore e architetto gesuita. Roma: Artemide, 2010. p. 89-92.

Perspectiva Pictorum et Architectorum - Le matrici originali. In: BÖSEL, R.; SALVIUCCI INSOLERA, L. Mirabili Disinganni: Andrea Pozzo (Trento 1642 - Vienna 1709). Pittore e architetto gesuita. Roma: Artemide, 2010. p. 189-200.

PALMER, R. 'All is very plain, upon inspection of the figure': the visual method of Andrea Pozzo's Perspectiva Pictorum et Architectorum. In: PALMER, R.; FRANGENBERG, T. The rise of the image: essays on the history of the illustrated Art book. Aldershot: Ashgate, 2003. p. 157-213.

'All is very plain, upon inspection of the figure': the visual method of Andrea Pozzo's Perspectiva Pictorum et Architectorum. In: PALMER, R.; FRANGENBERG, T. The rise of the image. Essays on the history of the illustrated Art book. Aldershot: Ashgate, 2003. p. 157-213.

SALVIUCCI INSOLERA, L. Le prime edizioni del Trattato. In: BATTISTI, A. Andrea Pozzo. Milano, Trento: Luni, 1996. p. 207-213.

SILVA, M. A. O tratado de Andrea Pozzo e a pintura de perspectiva em Minas Gerais. Belo Horizonte: Faculdade de Filosofia e Ciências Humanas, Universidade Federal de Minas Gerais, 2012. (Mestrado em História).

Perspectiva Pictorum et Architectorum. A perspectiva dos pintores e dos arquitetos, de Andrea Pozzo, SJ. Campinas: Instituto de Filosofia e Ciências Humanas, Universidade Estadual de Campinas, 2020. (Doutorado em História).

TINTO, A. Giovanni Giacomo Komarek tipografo a Roma nei secoli XVII-XVIII ed i suoi campionari di caratteri. La Bibliofilía, v. LXXV, n. 2, p. 189-225, 1973. 